Environment, Biodiversity \& Soil Security
(EBSS)
http://jenvbs.journals.ekb.eg//

\title{
Sustainable Irrigation and Fertilization Management of Successive Cultivated Sugar Beet and Cotton under Salt-affected Soil Conditions
}

\author{
Megahed Amer ${ }^{1 *}$, Mahmoud Aiad ${ }^{1}$, Sahar Rashed ${ }^{1}$ and Hassan El-Ramady ${ }^{2}$ \\ ${ }^{1}$ Soils Improvement Dept., Soils, Water and Environment Research Institute \\ (SWERI),Sakha Station, Agricultural Research Center (ARC), 9 El-Gammah St., \\ Giza, Egypt \\ ${ }^{2}$ Soil and Water Dept., Faculty of Agriculture, Kafrelsheikh Uni., 33156 Kafr El- \\ Sheikh, Egypt
}

\begin{abstract}
$\mathbf{T}$ WO field trials were carried out at the experimental farm, Sakha Agricultural Research Station, Kafr El-Sheikh Governorate, Egypt during two successive growing seasons (winter 2018/2019) and (summer 2019). The aim of this study was to investigate the impact of applied mineral and organic fertilizers under water stress on the physical, chemical and fertility of the soil properties as well as the productivity of sugar beet and cotton. The main investigated factors included irrigation treatments at 80,100 and $120 \%$, respectively from evaporation pan class $\mathrm{A}$. The fertilization treatments included applying $\mathrm{N}$-fertilizer at three rates of 100, 80 and $60 \% \mathrm{~N}$ from recommended dose in combination with compost. Two levels of potassium humate (i.e., 12 and $24 \mathrm{~kg} \mathrm{ha}^{-1}$ ) were also applied. The results showed that the studied soil chemical, physical properties and its fertility parameters were influenced by the individual treatments and recorded the most efficient values due to the interaction among of $\mathrm{I} 1 * \mathrm{~N} 3 * \mathrm{H} 2$ after sugar beet and cotton cultivation. The yield of sugar beet and cotton crops were significantly increased and recorded the highest values with the interaction of $\mathrm{I}_{1} * \mathrm{~N}_{3} * \mathrm{H}_{2}$ of treatments. Therefore, the irrigation and fertilization management could be considered a proper approach to sustain the soil and water resources in particular under arid and semi-arid regions. Further studies are needed for more and novel approaches in handling the salt-affected soils.
\end{abstract}

Keywords: Available nutrient, Soil bulk density, Soil salinity, Total porosity

\section{Introduction}

Salt affected soils represent about $6 \%$ of the world's land or about $20 \%$ from irrigated lands, which suffer from salinity and/or sodicity covering more than 400 million hectares (Arora, 2017). Salt affected soil is located in Nile Delta region and it occupies about $30 \%$ from Delta lands (2.0 Mha) (Mohamed, 2016). Also, the reclamation and sustainable management of these soils is a real challenge facing different countries such as Egypt, India, Pakistan, and Iran (Dagar et al., 2019). This challenge represents in the salinity and sodicity hazard, soil degradation and water scarcity in particular under arid and semi-arid conditions (Elbasiouny et al., 2017; Sharma and Singh, 2017; Aiad, 2019 and El-Ramady et al., 2019). Based on the problems of surface irrigation system, half of the irrigation water applied was with $24 \%$ going to deep percolation and $24 \%$ to run off (Joseph, 1980). The handling of salt-affected soils should include mobilization of $\mathrm{Na}^{+}$and then leaching these ions from soil profile to improve the soil properties in particular hydraulic conductivity (Day et al., 2019). Several soil amendments could be used to remediate and reclaim salt-affected soils such as gypsum, sulfur, and compost

*Corresponding author: megahedamer3@gmail.com

Received 02/12/2019; Accepted: 26/12/2019

DOI: $10.21608 /$ jenvbs.2019.20394.1076

(C)2019 National Information and Documentation Center (NIDOC) 
(Sharma and Singh, 2019). The application of compost has a positive effect on soil salinity due to its improving soil physical properties; hence it led to remove $\mathrm{Na}^{+}$from root zone (Day et al., 2019). Intensive cultivation, misuse and excessive use of chemical fertilizers may lead to loss of soil organic matter, have adverse effects on the environment and can threaten human and animal health as well as in food safety and quality. Fertilizers are needed for high yields particularly in nutrition poor soils. With increasing fertilizer prices and limited resources reserves, organic amendments like compost and manure as a source of nutrients and organic matter are considered an economic and environmental-friendly alternative (Abdel-Fattah and Merwad, 2016). Amer and El-Ramady (2015) concluded many benefits of organic ameliorators on improving soil health by enhancing soil quality parameters: physical fertility (soil porosity, aggregation, structure, bulk density, and water holding capacity), chemical fertility ( $\mathrm{pH}, \mathrm{EC}, \mathrm{CEC}$, ESP and nutrients). Amer and Hashem (2018) pointed out that application of compost had positive effect on EC due to improving the soil physical properties; hence it led to remove $\mathrm{Na}^{+}$far from root zone. Compost contains significant amounts of valuable plant nutrients including $\mathrm{N}, \mathrm{P}, \mathrm{K}, \mathrm{Ca}, \mathrm{Mg}$ and $\mathrm{S}$ as well as a variety of essential trace elements (Madeleine et al., 2005). Thus, compost can be defined as an organic multi-nutrient fertilizer (Amlinger et al. 2007).By an appropriate mixture of these, organic input materials, humus and nutrientrich compost substrates can be produced which serving as a substitute for commercial mineral fertilizers in agriculture (Amlinger et al., 2007). Compost use does not only improve the growth and productivity of crops in terms of quantity but it could be also proved that quality of agricultural products is influenced in a positive way (Getinet 2016). The key is deprotonation of humic and fluvic acids, which leads to formation of large organic poly anions. They can bind clay particles into micro-aggregates by forming $[(\mathrm{Cl}-\mathrm{P}-\mathrm{OM}) \mathrm{x}] \mathrm{y}$ complexes where $\mathrm{Cl}, \mathrm{P}$, and $\mathrm{OM}$ are clay particles, polyvalent cations and organic matter (Amini et al. 2016). For salt-affected soils, the addition of organic matter (OM) can accelerate the leaching of $\mathrm{Na}^{+}$, decrease the ESP and electrical conductivity (EC), and increase water infiltration, water-holding capacity, and aggregate stability (Tejada et al., 2006 and Mahdy, 2011). The sustainable practices of irrigation and fertilization have received considerable critical attention.
Recent developments in the field of irrigation and fertilization have led to a renewable interest in their practices under salt-affected soil conditions.

Therefore, the management of irrigation and fertilization practices was and still one of the most important issues in the sustainable agriculture in particular under salt-affected soil conditions. So, this investigation was carried out to study the effect of management of irrigation water, $\mathrm{N}$-fertilization and organic amendments effects on some soil properties and productivity of sugar beet and cotton under salinity stress conditions.

\section{Materials and Methods}

Field trials were carried out at Sakha Agricultural Research station farm, Kafr ElSheikh Governorate, Egypt. During two successive growing seasons with cultivation of sugar beet (winter 2018/2019) and cotton cv.Giza94 (summer 2019) under salt-affected soil conditions. The station coordinates exists at $31^{\circ} 05 \mathrm{~N}$ latitude and $30^{\circ} 57 \mathrm{E}$ longitude. The experiments were conducted in Split-Split plot design with three replications; the main plots were assigned to irrigation, i.e., $\mathrm{I}_{1}, \mathrm{I}_{2}$ and $\mathrm{I}_{3}$ at 80,100 and $120 \%$ from evaporation pan class $\mathrm{A}$, respectively.

The approach of pan evaporation method To define the time of irrigation, measure water use for a short period of time, keeping track of the value or depth at the start of the season or when the pan is refilled following heavy rain or irrigation. A check book is used to schedule irrigations. The value for daily water use or for a few days is subtracted from the stored soil water is exhausted, it is time to irrigate. $\mathrm{I}_{1}$ : irrigation depth applied $82.0 \mathrm{~mm}(80 \% \times 102.3 \mathrm{~mm})$. I : irrigation depth applied $102.3 \mathrm{~mm}(100 \% \times$ $102.3 \mathrm{~mm}) . \mathrm{I}_{3}$ : irrigation depth applied $123.0 \mathrm{~mm}$ $(120 \% \times 102.3 \mathrm{~mm})$, according to allowable soil moisture depletion at $60 \%$ of available water had evaporated from pan evaporation.

Taking into consideration pan coefficient, crop coefficient of sugar beet and cotton for different growth stages was taken from FAO irrigation and drainage technical paper No. 56 (Table 1). The inflow rate was measured with a rectangular sharp crested weir. The flow rate was measured using the equation as described by (Masoud 1969). $\mathrm{Q}=\mathrm{C} \mathrm{L} \mathrm{H3} / 2$ where: $\mathrm{Q}=$ discharge $\left(\mathrm{m}^{3} / \mathrm{sec}.\right), \mathrm{L}=$ length of the crest in meters, $\mathrm{H}=$ head in meters, $\mathrm{C}=$ Empirical coefficient that must be determined from discharge measurement. 
Subplots were devoted to combinations of three $\mathrm{N}$-fertilizer rates using different ratios from $\mathrm{N}$-mineral and $\mathrm{N}$-organic. The first dose $\left(\mathrm{N}_{1}\right)$ was $100 \%$ mineral $\mathrm{N}$-fertilizer only, where $\mathrm{N}_{2}$ included $80 \% \mathrm{~N}$-mineral $+20 \%$ from $\mathrm{N}$ as compost from the $\mathrm{N}$-recommended dose and $\mathrm{N}_{3}$ was $60 \% \mathrm{~N}$-mineral $+40 \% \mathrm{~N}$ as compost. The sub-sub plot included two levels of potassium humate (e.g., 12and $24 \mathrm{kgha}^{-}$ $\left.{ }^{1}\right)$. The recommended of $\mathrm{N}$-rate for sugar beet and cotton was 192 and $180 \mathrm{kgha}^{-1}$, respectively and were added in the form of urea $(46.5 \% \mathrm{~N})$ and ammonium nitrate $(33 \% \mathrm{~N})$, respectively. Rice crop was cultivated before sugar beet. The plot area was $150 \mathrm{~m}^{2}$ (30m length $\times 5 \mathrm{~m}$ width). The compost was added to the soil and mixed with the upper layer before planting of sugar beet (2.6 and 5.2 $\mathrm{Mg} \mathrm{ha}^{-1}$ ) and cotton (2.8 and $5.5 \mathrm{Mg}$ $\mathrm{ha}^{-1}$ ) for 20 and $40 \%$ from recommended nitrogen dose. The chemical composition(in $\mathrm{mg} \mathrm{kg}^{-1}$ ) of compost included N (1.4), P (0.68), K (2.10), organic matter (38.9), $\mathrm{C} / \mathrm{N}$ ratio (18:1), whereas $\mathrm{pH}$ (7.61) soil salinity or EC (2.91 $\left.\mathrm{dS} \mathrm{m}^{-1}\right)$ and moisture content $(28.15 \%)$, where the composting was from mixture of residual plants and animals. The chemical composition (in $\mathrm{mg} \mathrm{kg}^{-1}$ ) of humate potassium were humic acid (75), $\mathrm{K}_{2} \mathrm{O}$ (10), fluvic (4) and iron (2), soil acidity or $\mathrm{pH}$ (6.70). Soil samples were collected at depths $(0-20,20$ 40 and $40-60 \mathrm{~cm}$ ) before experiments and after harvesting of both crops for all treatments to carry out some physical and chemical analysis. Salinity was determined in saturated soil paste extract according to Page et al. (1982). Soil bulk density and total porosity of different soil layers for all treatments were measured before experiments and after harvesting using the core sampling technique as described by Campbell (1994). The meteorological data from Sakha Station during the growing seasons are presented in Table 1.The available nutrients of $\mathrm{N}, \mathrm{P}$ and $\mathrm{K}$ were measured according to the standard methods of Page et al. (1982) as shown in Table 2.Sugar beet (Beta vulgaris L.) was sown on $1^{\text {th }}$ September, 2018 and harvested on $25^{\text {th }}$ Feb. 2019. While cotton (Gossypium spp., Giza 94) was sown on $10^{\text {th }}$ April, 2019 and harvested on $30^{\text {th }}$ September, 2019, respectively. Samples of cotton plants were taken from all treatments for determination of yield $\left(\mathrm{Mg} \mathrm{ha}^{-1}\right)$, whereas sugar, root and shoot of sugar beet $\left(\mathrm{Mgha}^{-1}\right)$ were recorded after harvesting. The sugar content in roots of sugar beet was measured in the Factory of Sugar, El-Hamoul, Kafr ElSheikh.

TABLE 1. Climatological data, potential evapotranspiration $\left(\mathbf{E T}_{0}\right)$ and maximum evapotranspiration $\left(\mathrm{ET}_{\mathrm{m}}\right)$ for sugar beet and cotton during seasons (2018/2019)

\begin{tabular}{|c|c|c|c|c|c|c|c|c|c|c|c|}
\hline \multirow[b]{2}{*}{ Month } & \multirow[b]{2}{*}{ T. $\left(\mathrm{C}^{\circ}\right)$} & \multirow[b]{2}{*}{$\begin{array}{c}\text { R.H. } \\
(\%)\end{array}$} & \multirow[b]{2}{*}{$\begin{array}{c}\text { W.V. } \\
(\mathbf{k m} \\
\left.\mathrm{day}^{-1}\right)\end{array}$} & \multirow[b]{2}{*}{$\begin{array}{c}\text { period } \\
\text { day }\end{array}$} & \multicolumn{2}{|c|}{ P.E. } & \multirow[b]{2}{*}{ K pain } & \multirow[b]{2}{*}{$\mathbf{E T}_{0}$} & \multirow[b]{2}{*}{$\mathbf{K}_{\mathbf{c}}$} & \multicolumn{2}{|c|}{$\mathbf{E T}_{\mathrm{m}}$} \\
\hline & & & & & $\overbrace{\tilde{E}}^{\mathbb{Z}}$ & ฮ & & & & $\mathbf{c m}$ & $\mathbf{m}^{2}$ \\
\hline \multicolumn{12}{|c|}{ Sugar beet (2018/2019) } \\
\hline Sept. & 28.2 & 65.7 & 68.7 & 30 & 0.498 & 14.94 & 0.8 & 11.95 & 0.5 & 5.98 & 602.38 \\
\hline Oct. & 25.1 & 66.1 & 57.9 & 30 & 0.324 & 9.72 & 0.8 & 7.78 & 0.9 & 7.00 & 705.44 \\
\hline Nov. & 21.2 & 70.6 & 24.2 & 30 & 0.16 & 4.8 & 0.8 & 3.84 & 1.2 & 4.61 & 464.49 \\
\hline Dec. & 16.7 & 67.8 & 33.1 & 31 & 0.108 & 3.348 & 0.8 & 2.68 & 1.2 & 3.21 & 323.98 \\
\hline Jan. & 15.6 & 72.6 & 28.6 & 31 & 0.114 & 3.534 & 0.8 & 2.83 & 1.2 & 3.39 & 341.98 \\
\hline Feb. & 17.0 & 72.2 & 45.7 & 25 & 0.178 & 4.45 & 0.8 & 3.56 & 0.7 & 2.49 & 251.19 \\
\hline \multicolumn{12}{|c|}{ Cotton (2019) } \\
\hline Apr. & 23.2 & 57.2 & 68.4 & 20 & 0.413 & 8.26 & 0.8 & 6.61 & 0.4 & 2.64 & 266.43 \\
\hline May. & 28.7 & 65.75 & 103.5 & 30 & 0.683 & 20.49 & 0.8 & 16.39 & 0.7 & 11.47 & 1156.62 \\
\hline jun & 30.5 & 69.8 & 83.8 & 31 & 0.846 & 26.226 & 0.8 & 20.98 & 1.15 & 24.13 & 2432.09 \\
\hline july & 31.0 & 70.65 & 68.7 & 30 & 0.808 & 24.24 & 0.8 & 19.39 & 1.15 & 22.30 & 2247.92 \\
\hline Agus. & 31.6 & 68.15 & 76.9 & 31 & 0.683 & 21.173 & 0.8 & 16.94 & 1.15 & 19.48 & 1963.50 \\
\hline Sept. & 30.2 & 57.2 & 68.4 & 30 & 0.59 & 17.7 & 0.8 & 14.16 & 0.6 & 8.50 & 856.40 \\
\hline
\end{tabular}

Abbreviations: T. $\left(\mathbf{C}^{\circ}\right)$, average both of maximum and minimum of temperature; R.H.: Relative Humidity; W.V.: Wind velocity (at $2 \mathrm{~m}$ height); P.E.: Pan Evaporation. K pain, coefficient of evapotranspiration. $\mathbf{E T}_{\mathbf{0}}$, potential evapotranspiration. $\mathbf{K}_{\mathrm{c}}, \mathbf{E T}_{\mathbf{m}}$, maximum evapotranspiration $\left(\mathrm{m}^{2} \mathrm{ha}^{-1}\right)$, rain effective $\left(161 \mathrm{~m}^{3} /\right.$ winter season $)$ 
TABLE 2. Some physical and chemical properties of the experimental soil

\begin{tabular}{|c|c|c|c|c|c|c|c|c|c|c|}
\hline \multirow{3}{*}{$\begin{array}{l}\text { Soil depth } \\
\text { (cm) }\end{array}$} & \multicolumn{10}{|c|}{ Soil physical properties } \\
\hline & \multicolumn{4}{|c|}{ Soil moisture characteristics } & \multicolumn{6}{|c|}{ Particle size distribution $\left(\mathrm{g} \mathrm{kg}^{-1}\right)$} \\
\hline & $\begin{array}{l}\text { F.C } \\
(\%)\end{array}$ & $\begin{array}{l}\text { W.P. } \\
\text { (\%) }\end{array}$ & $\begin{array}{l}\text { A.W. } \\
(\%)\end{array}$ & $\begin{array}{c}\text { B.D. } \\
\left(\mathrm{kg} \mathrm{m}^{-3}\right)\end{array}$ & Sand & \multicolumn{2}{|c|}{ Silt } & \multicolumn{2}{|c|}{ Clay } & Soil texture \\
\hline $0-20$ & 44.11 & 22.01 & 22.10 & 1.37 & 173.1 & \multicolumn{2}{|c|}{255.1} & \multicolumn{2}{|c|}{571.8} & clay \\
\hline $20-40$ & 40.52 & 20.28 & 20.24 & 1.38 & 188.5 & \multicolumn{2}{|c|}{247.6} & \multicolumn{2}{|c|}{563.9} & clay \\
\hline $40-60$ & 38.03 & 19.03 & 19.00 & 1.42 & 190.6 & \multicolumn{2}{|c|}{251.2} & \multicolumn{2}{|c|}{558.2} & clay \\
\hline \multicolumn{11}{|c|}{ Soil chemical properties } \\
\hline $\begin{array}{l}\text { Soil depth } \\
\quad(\mathrm{cm})\end{array}$ & $\mathrm{pH}$ & $\begin{array}{c}\mathrm{EC} \\
\left(\mathrm{dS} \mathrm{m}^{-1}\right)\end{array}$ & \multicolumn{2}{|c|}{$\begin{array}{l}\text { ESP } \\
(\%)\end{array}$} & $\begin{array}{c}\text { CEC } \\
\left(\mathrm{cmol}_{\mathrm{e}} \mathrm{kg}^{-1}\right)\end{array}$ & \multicolumn{3}{|c|}{$\left(\mathrm{mg} \mathrm{kg}^{-1}\right)$} & \multicolumn{2}{|c|}{$\left(\mathrm{g} \mathrm{kg}^{-1}\right)^{3}$} \\
\hline $0-20$ & 8.2 & 6.6 & & 13.6 & 39.1 & 25.8 & 9.5 & 245 & 18.9 & 29.1 \\
\hline $20-40$ & 8.2 & 7.5 & & 14.7 & 38.0 & 26.9 & 9.3 & 242 & 16.2 & 28.2 \\
\hline $40-60$ & 8.4 & 10.3 & & 15.3 & 36.3 & 22.0 & 9.1 & 241 & 14.5 & 23.1 \\
\hline
\end{tabular}

F.C.: Field Capacity; W.P.: Wilting Point; A.W.: Available Water; B.D.: Bulk Density; pH: was determined in soil water suspension (1:2.5); EC: was determined in saturated soil paste extract; ESP: Exchangeable Sodium Percent; CEC: Cation Exchange Capacity; OM: Organic Matter; N, P, K: available of nitrogen, phosphour and potassium

According to Natural Resources Conservation Service (NRCS), Oregon State University, USA, the soil of experiment can be classified as saline soil where $(\mathrm{EC}>4 \mathrm{dS} \mathrm{m}-1, \mathrm{ESP}<15 \%$ and soil $\mathrm{pH}<8.5$ ) (Horneck et al. 2007).

The data were analyzed statistically by analysis of variance (ANOVA) using M-State program according to Gomez and Gomez (1984). Mean separation procedure was performed using LSD, F test at a 0.05 level of significance.

\section{Results and Discussion}

\section{Water applied}

Total amount of water applied $\left(\mathrm{m}^{3} \mathrm{ha}^{-1}\right)$ including rainfall $(\mathrm{mm})$ of sugar beet and cotton crop was shown in Fig. 1. It has been noticed that the total amount of water applied for irrigation treatments, were in the following order: $80 \%$ pan evaporation $>100 \%$ pan evaporation $>120 \%$ pan evaporation, whereas, the values of water applied of sugar beet were $7147.2,6504$ and $5901.6 \mathrm{~m}^{3}$ $\mathrm{ha}^{-1}$ for I1, I2 and I3, respectively. The values of water applied recorded 108012, 9871.2 and $9294.5 \mathrm{~m}^{3} \mathrm{ha}^{-1}$ with $\mathrm{I} 1, \mathrm{I} 2$ and I3, respectively for cotton crop. It was observed that irrigation at $80 \%$ pan evaporation received amount of water higher than that received under both of irrigation at $100 \%$ or $120 \%$ pan evaporation due to the more number of irrigations under $\left(I_{1}\right)$ treatment. These results are supported by Moursi et al. (2019)

\section{Soil chemical properties}

In this study, sugar beet was selected as promising crop in removing a huge amount of sodium into its shoots and then helps in decrease the sodicity and /or soil salinity hazard in saltaffected soils. Cotton was also selected due to its benefits for soils in particular its residue stalks after harvesting, which increase the soil content of organic matter. To study the impact of different applied treatments on soil chemical properties, salt distribution (EC) and exchangeable sodium percent (ESP) in soil profile have been determined (Table 3). Data showed that the mean values of EC and ESP in root zone up to $60 \mathrm{~cm}$ depth were significantly decreased due to the leaching effect of irrigation treatments. The highest amount of irrigation water (treatment $\mathrm{I}_{1}$ ) led to leach a considerable amount of salts in soil profile as well. The lowest values of soil salinity (EC) were recorded in case of treatment $\mathrm{I}_{1}$ (4.97, 6.67 and $9.39 \mathrm{dS} \mathrm{m}^{-1}$ for each depth, respectively) under cultivation of sugar beet. It is also noticed that a relative decrease in soil EC by $25.61,11.07$ and $8.83 \%$ for soil depth $0-20$, 20-40 and 40-60 cm, respectively after sugar beet harvesting, whereas this reduction in soil salinity distribution after cotton harvesting were 29.24, 14.53 and $12.33 \%$ in case of treatment $I_{1}$ with the different soil depths, respectively as compared with EC before experiment.

With regard to ESP, the data showed that the relative decrease in the soil ESP values were (27.9, 23.0 and $12.3 \%$ ) after sugar beet harvesting for 0-20, 20-40 and 40-60 cm soil depths, respectively, while the corresponding reduction in ESP values after cotton harvesting were $31.2,23.7$ and $14.7 \%$ in case of $I_{1}$ also with the different soil depths, respectively as compared with the values of ESP obtained before experiment. Similar results were 


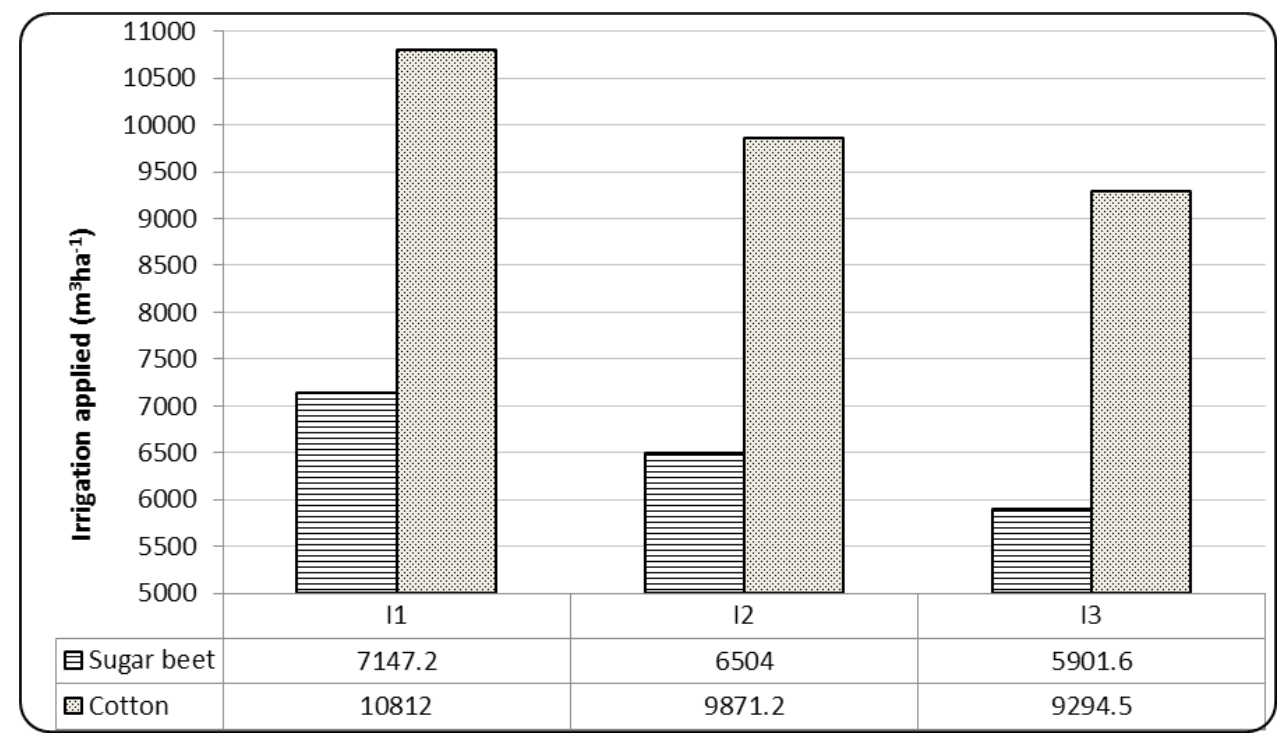

Fig. 1.Water applied of sugar beet and cotton during winter season 201/2019 and summer of 2019

obtained by Badr (1980) who found an increase in the soil salt concentration. The same trend was observed in the salt distribution in soil profile $(0-60$ $\mathrm{cm})$ with a significant decrease due to fertilization treatments. The lowest values were recorded at $\mathrm{N}_{3}(60 \% \mathrm{~N}+40 \%$ compost from recommended nitrogen). The data indicated that the soil salinity values were relatively decreased by $34.2,30.95$ and $28.36 \%$ with studied soil depths, respectively, after sugar beet harvesting. While the reduction of salt distribution in soil profile after cotton was 20, 10.4 and $9.61 \%$ with the same soil depths, respectively. With regard to ESP (\%), the data showed that ESP (\%) were decreased by 24.0 , 21.1 and $11.5 \%$ after harvesting of sugar beet for 0-20, 20-40 and 40-60 cm soil depth respectively, While the ESP were decreased by 26.8, 22.9 and $13.6 \%$ at $\mathrm{N}_{3}$ for the same soil depths, respectively, after cotton harvesting as compared with the values of ESP before experiment.

The K-humate application casued a significant decrease in both EC and ESP values. The lowest values of EC were 17.27, 6.67 and 5.92\% due to by application of $24 \mathrm{kgha}^{-1}$ after sugar beet harvesting and19.55, 9.73 and $8.35 \%$ after cotton harvesting for studied soil depths, respectively. Concerning the mean values of ESP, the data showed a relative decrease in ESP were 23.7, 21.0 and $11.2 \%$ after sugar beet harvesting and 26.7, 22.1 and $13.1 \%$ after cotton harvesting for the same studied soil depths, respectively. The decrease in soil salinity may be due to the role of humic substances in improving the soil physical and chemical properties. These results are also supported by Amer and Hashem (2018).
The interaction effect between irrigation and $\mathrm{N}$-fertilization treatments could be explained in frame of the leaching impact of the irrigation water and the integrated $\mathrm{N}$-fertilization as well as the role of compost in supporting cultivated crops. Table 3 indicated that there were highly significant effects on salt distribution and ESP in soil profile after harvesting of sugar beet and cotton due to the interaction effect among I*N, $\mathrm{I}^{*} \mathrm{~K}, \mathrm{~N}^{*} \mathrm{~K}$ and $\mathrm{I}^{*} \mathrm{~N}^{*} \mathrm{~K}$, where the lowest values were obtained in case of the interaction among $\mathrm{I}_{1} * \mathrm{~N}_{3} * \mathrm{~K}_{2}$ with a reduction in EC by $30.61,15.87$ and $16.8 \%$ after sugar beet harvesting and 35.61 , 18.67 and $21.36 \%$ after cotton harvesting under studied soil depths, respectively (Fig. 2).With regarded to ESP, a relative decrease in ESP were 31.6, 23.8 and $13.0 \%$ after sugar beet harvesting and $36.3,26.1$ and $16.5 \%$ after cotton harvesting under different studied soil depths, respectively as compared with ESP before cultivation of each crop. These results supported by Mahmoud and Ahmad (2005) who found that addition of water in excess of that required by the crop can be applied to ensure leaching of salts.

\section{Soil physical properties}

Soil bulk density

The soil physical properties represent distinguished feature of salt-affected soils including deep cracks, soapy feature of soil due to high $\mathrm{Na}$ content as well as the high values in soil bulk density. Results in Table 4 revealed that the treatments applied seemed to be effective in producing relatively low values of soil bulk density especially in the surface layer. Soil bulk 
TABLE 3. Salt distribution in soil profile $\left(\mathrm{EC}, \mathrm{dS} \mathrm{m}^{-1}\right)$ and exchangeable sodium percent (ESP, \%) as affected by treatments after harvesting of each crop

\begin{tabular}{|c|c|c|c|c|c|c|}
\hline \multirow{3}{*}{ Treatments } & \multicolumn{4}{|c|}{ Sugar beet } & \multicolumn{2}{|l|}{ Cotton } \\
\hline & \multicolumn{6}{|c|}{ Soil depth (cm) } \\
\hline & $0-20$ & $20-40$ & $40-60$ & $0-20$ & $20-40$ & $40-60$ \\
\hline \multicolumn{7}{|c|}{ Soil salinity $\left(\mathrm{EC}, \mathrm{dSm}^{-1}\right)$} \\
\hline $\mathrm{I}_{1}$ & $4.97 \mathrm{c}$ & $6.67 \mathrm{c}$ & $9.39 \mathrm{c}$ & $4.67 \mathrm{c}$ & $6.47 \mathrm{c}$ & $9.03 \mathrm{c}$ \\
\hline $\mathrm{I}_{2}$ & $5.32 \mathrm{~b}$ & $7.14 b$ & $9.89 \mathrm{~b}$ & $5.11 \mathrm{~b}$ & $6.83 b$ & $9.65 b$ \\
\hline $\mathrm{I}_{3}$ & $6.39 \mathrm{a}$ & $7.41 \mathrm{a}$ & $10.09 \mathrm{a}$ & $6.33 \mathrm{a}$ & $7.19 \mathrm{a}$ & $9.87 \mathrm{a}$ \\
\hline $\mathrm{F}_{\text {test }}$ & $* *$ & $* *$ & $* *$ & $* *$ & $* *$ & $* *$ \\
\hline $\mathrm{N}_{1}$ & $5.62 \mathrm{a}$ & $7.20 \mathrm{a}$ & $9.97 \mathrm{a}$ & $5.45 \mathrm{a}$ & $6.99 \mathrm{a}$ & $9.71 \mathrm{a}$ \\
\hline $\mathrm{N}_{2}$ & $5.57 \mathrm{~b}$ & $7.07 \mathrm{~b}$ & $9.82 b$ & $5.39 \mathrm{~b}$ & $6.83 b$ & $9.54 \mathrm{~b}$ \\
\hline $\mathrm{N}_{3}$ & $5.46 \mathrm{c}$ & $6.95 \mathrm{c}$ & $9.57 \mathrm{c}$ & $5.28 \mathrm{c}$ & $6.72 \mathrm{c}$ & $9.31 \mathrm{c}$ \\
\hline $\mathrm{F}_{\text {test }}$ & $* *$ & $* *$ & $* *$ & $* *$ & $* *$ & $* *$ \\
\hline $\mathrm{H}_{1}$ & $5.64 \mathrm{a}$ & $7.15 \mathrm{a}$ & $9.89 \mathrm{a}$ & $5.44 \mathrm{a}$ & $6.89 a$ & $9.60 \mathrm{a}$ \\
\hline $\mathrm{H}_{2}$ & $5.46 \mathrm{~b}$ & $7.0 \mathrm{~b}$ & $9.69 b$ & $5.31 \mathrm{~b}$ & $6.77 b$ & $9.44 \mathrm{~b}$ \\
\hline $\mathrm{F}_{\text {test }}$ & $* *$ & $* *$ & $* *$ & $* *$ & $* *$ & $* *$ \\
\hline$I^{*} \mathrm{~N}$ & $* *$ & $* *$ & $*$ & $* *$ & $* *$ & $* *$ \\
\hline$I^{*} \mathrm{H}$ & $* *$ & $* *$ & $* *$ & $* *$ & $* *$ & $* *$ \\
\hline $\mathrm{N}^{*} \mathrm{H}$ & $* *$ & $* *$ & $* *$ & $* *$ & $* *$ & $* *$ \\
\hline $\mathrm{I} * \mathrm{~N} * \mathrm{H}$ & $* *$ & $* *$ & $* *$ & $* *$ & $* *$ & $* *$ \\
\hline
\end{tabular}

Exchangeable sodium percent (ESP, \%)

\begin{tabular}{|c|c|c|c|c|c|c|}
\hline $\mathrm{I}_{1}$ & $9.81 \mathrm{c}$ & $11.32 \mathrm{c}$ & $13.42 \mathrm{c}$ & $9.36 \mathrm{c}$ & $11.21 \mathrm{c}$ & $13.05 \mathrm{c}$ \\
\hline $\mathrm{I}_{2}$ & $10.22 b$ & $11.72 b$ & $13.67 \mathrm{~b}$ & $9.87 \mathrm{~b}$ & $11.48 \mathrm{~b}$ & $13.42 b$ \\
\hline $\mathrm{I}_{3}$ & $11.25 \mathrm{a}$ & $11.94 \mathrm{a}$ & $13.78 \mathrm{a}$ & $11.01 \mathrm{a}$ & $11.77 \mathrm{a}$ & $13.58 \mathrm{a}$ \\
\hline $\mathrm{F}_{\text {test }}$ & $* *$ & $* *$ & $* *$ & $* *$ & $* *$ & $* *$ \\
\hline $\mathrm{N}_{1}$ & $10.49 \mathrm{a}$ & $11.74 \mathrm{a}$ & $13.72 \mathrm{a}$ & $10.20 \mathrm{a}$ & $11.61 \mathrm{a}$ & $13.46 \mathrm{a}$ \\
\hline $\mathrm{N}_{2}$ & $10.45 b$ & $11.65 \mathrm{~b}$ & $13.61 \mathrm{~b}$ & $10.09 \mathrm{~b}$ & $11.50 \mathrm{~b}$ & $13.37 \mathrm{~b}$ \\
\hline $\mathrm{N}_{3}$ & $10.33 \mathrm{c}$ & $11.60 \mathrm{c}$ & $13.54 \mathrm{c}$ & $9.96 \mathrm{c}$ & $11.34 \mathrm{c}$ & $13.22 \mathrm{c}$ \\
\hline $\mathrm{F}_{\text {test }}$ & $* *$ & $* *$ & $* *$ & $* *$ & $* *$ & $* *$ \\
\hline $\mathrm{H}_{1}$ & $10.47 \mathrm{a}$ & $11.71 \mathrm{a}$ & $13.66 \mathrm{a}$ & $10.19 a$ & $11.52 \mathrm{a}$ & $13.40 \mathrm{a}$ \\
\hline $\mathrm{H}_{2}$ & $10.38 b$ & $11.61 \mathrm{~b}$ & $13.59 \mathrm{~b}$ & $9.97 b$ & $11.45 b$ & $13.30 \mathrm{~b}$ \\
\hline $\mathrm{F}_{\text {test }}$ & $* *$ & $* *$ & $*$ & $* *$ & $* *$ & $*$ \\
\hline $\mathrm{I}^{*} \mathrm{~N}$ & $* *$ & $* *$ & $* *$ & $* *$ & $* *$ & $* *$ \\
\hline $\mathrm{I}^{*} \mathrm{H}$ & $* *$ & $* *$ & $* *$ & $* *$ & $* *$ & $* *$ \\
\hline $\mathrm{N}^{*} \mathrm{H}$ & $* *$ & $* *$ & $* *$ & $* *$ & $* *$ & $* *$ \\
\hline $\mathrm{I} * \mathrm{~N} * \mathrm{H}$ & $* *$ & $* *$ & $*$ & $* *$ & $* *$ & $* *$ \\
\hline
\end{tabular}

Treatments: $\mathrm{I}_{1}, \mathrm{I}_{2}$ and $\mathrm{I}_{3}$ represent 80,100 and $120 \%$ from standard evaporation pan class A pan. $\mathrm{N}_{1}: 100 \%$ from recommended nitrogen, $\mathrm{N}_{2}: 80 \%$ from recommended nitrogen + the rest from compost and $\mathrm{N}_{3}: 80 \%$ from recommended nitrogen + the rest from compost, $\mathrm{H}_{1}$ and $\mathrm{H}_{2}: 12$ and $24 \mathrm{~kg} \mathrm{ha}^{-1} \mathrm{~K}$-humate

Env. Biodiv. Soil Security (2019) 

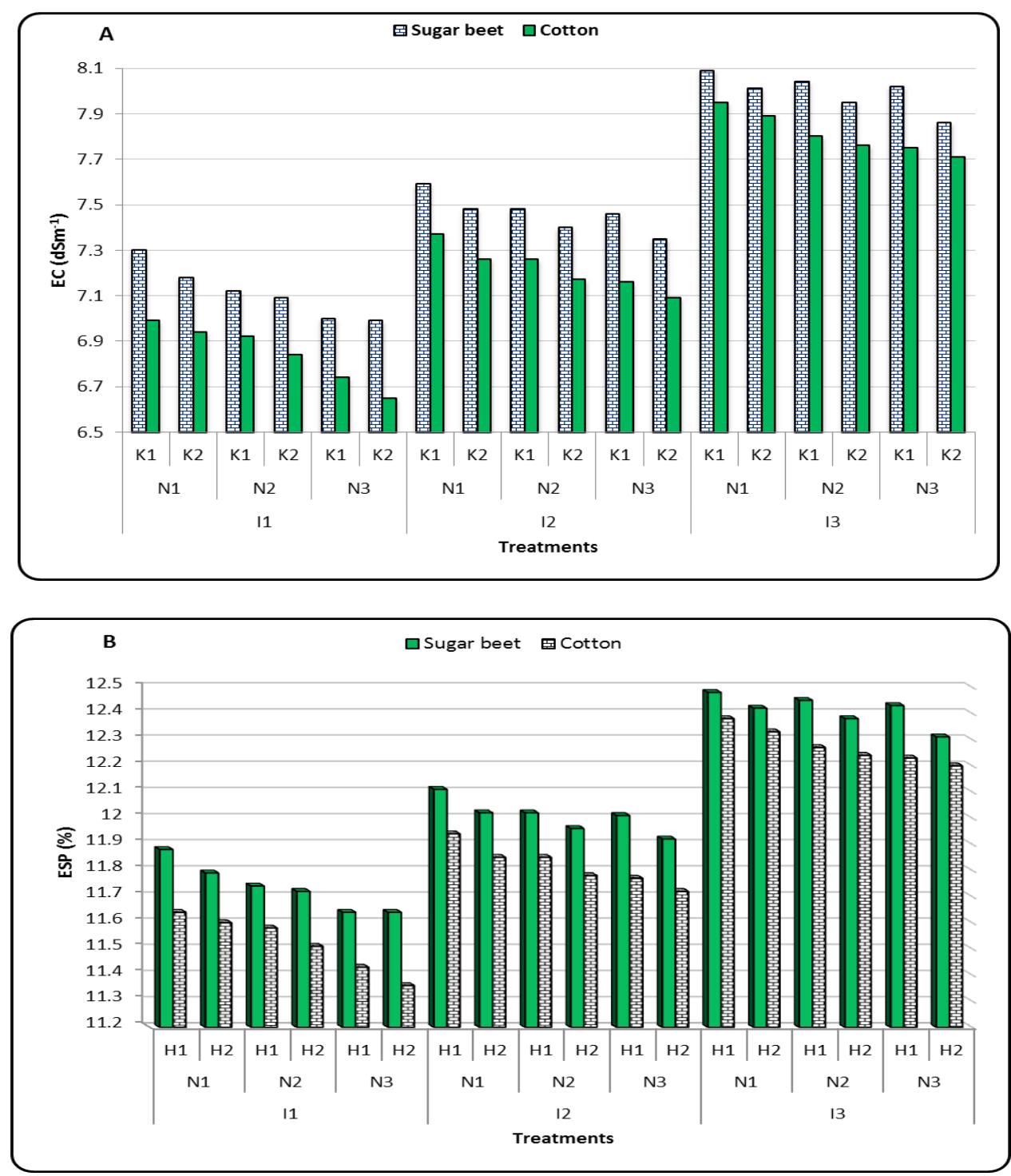

Fig. 2. Salt distribution (A) and ESP (B) in soil profile after harvesting of sugar beet and cotton as affected by different treatments and their interaction

density (BD) ranged from 1.37 to $1.42 \mathrm{Mg} \mathrm{m}^{-3}$ before experiment setup, while after cultivation of two studied crops, bulk density values (BD) were reduced and varied from 1.30 to 1.34 $\mathrm{Mg} \mathrm{m} \mathrm{m}^{-3}$. Table 4 showed that soil BD slightly decreased due to the irrigation treatments, where the relative decrease were $(6.8,4.6$ and $4.7 \%)$ and $(7.4,5.4$ and $5.4 \%)$ after harvesting of sugar beet and cotton at different soil depths. Also, data referred that soil BD significantly decreased by application of nitrogen and lowest values were recorded by $\mathrm{N}_{3}$ treatment. Regarding to the effect of applied K-humate on soil bulk density, the data showed that the application of $24 \mathrm{kgha}^{-1}$ potassium humate recorded the lowest values of bulk density. However, the relative reduction in soil BD were 3.9, 3.9 and $5.9 \%$ after harvesting of sugar beet, whereas in case of cotton the values were $3.8,4.6$ and $6.5 \%$ at studied soil depths, respectively. This may be reflected the role of compost in increasing the soil aggregation, increasing the soil porosity and decreasing soil bulk density as well as improving soil properties (El-Henawy et al. 2016).Also, data in Table (4) indicated that soil bulk density was significantly decreased due to interaction effect among applied treatments I*N, I*H, N*H and I* $\mathrm{N}^{*} \mathrm{H}$, while the treatment $\mathrm{I}_{1} * \mathrm{~N}_{3} * \mathrm{H}_{2}$ recorded the lowest values of soil bulk density. 


\section{Total porosity}

Soil aeration is considered one of the most soil factors controlling the plant growth, whereas the total soil porosity is a soil physical property depending mainly on soil texture. Table 4 showed that total porosity (\%) was slightly increased with increasing irrigation water and recorded highest values with $\mathrm{I}_{1}$ under different soil depth up to $60 \mathrm{~cm}$. Also, data revealed that applied $\mathrm{N}$-fertilizer had a significant effect on increasing the soil porosity and recorded the highest values with $\mathrm{N}_{3}$. This effect may be due to role of the applied compost in improving soil aggregation and soil physical properties. With regard to applied K-humate, soil porosity was significantly increased since the highest values were recorded at level of $24 \mathrm{kgha}^{-1} \mathrm{~K}$-humate. These results are supported by Amer and El-Ramady (2015).Also the same data in Table 4 showed that soil porosity was significantly increased and recorded the highest values due to the following interactions: $I^{*} \mathrm{~N}, \mathrm{I}^{*} \mathrm{H}, \mathrm{N}^{*} \mathrm{H}$ and $\mathrm{I}^{*} \mathrm{~N}^{*} \mathrm{H}$, where the highest values were recorded with treatment of $\mathrm{I}_{1} * \mathrm{~N}_{3} * \mathrm{H}_{2}$

TABLE 4. Soil bulk density $\left(\mathrm{Mg} \mathrm{m}^{-3}\right)$ and total soil porosity (\%) as affected by different treatments after harvesting of sugar beet and cotton crops

\begin{tabular}{|c|c|c|c|c|c|c|}
\hline \multirow{3}{*}{ Treatments } & \multicolumn{4}{|c|}{ Sugar beet } & \multicolumn{2}{|l|}{ Cotton } \\
\hline & \multirow[b]{2}{*}{$0-20$} & & \multicolumn{2}{|c|}{ Soil depth (cm) } & \multirow[b]{2}{*}{$20-40$} & \multirow[b]{2}{*}{$40-60$} \\
\hline & & $20-40$ & $40-60$ & 0-20 & & \\
\hline & \multicolumn{5}{|c|}{ Soil bulk density $\left(\mathrm{Mg} \mathrm{m}^{-3}\right)$} & \\
\hline $\mathbf{I}_{1}$ & 1305 & 1.316 & 1.324 & 1.296 & 1.305 & 1.315 \\
\hline$I_{2}$ & $\begin{array}{l}1.505 \\
1.324\end{array}$ & $\begin{array}{l}1.316 \\
1.333\end{array}$ & 1.343 & $\begin{array}{l}1.296 \\
1315\end{array}$ & $\begin{array}{l}1.305 \\
1.324\end{array}$ & 1.334 \\
\hline$I_{3}$ & 1.325 & $\begin{array}{l}1.333 \\
1.335\end{array}$ & 1.345 & $\begin{array}{l}1.315 \\
1.317\end{array}$ & $\begin{array}{l}1.324 \\
1.327\end{array}$ & 1.337 \\
\hline $\mathbf{F}_{\text {test }}$ & ns & $\mathrm{ns}$ & ns & ns & $\mathrm{ns}$ & ns \\
\hline $\mathrm{N}_{1}$ & $1.322 \mathrm{a}$ & $1.331 \mathrm{a}$ & $1.324 \mathrm{a}$ & $1.314 \mathrm{a}$ & $1.322 \mathrm{a}$ & $1.333 \mathrm{a}$ \\
\hline $\mathbf{N}_{2}$ & $1.322 \mathrm{a}$ & $1.331 \mathrm{a}$ & $1.342 \mathrm{a}$ & $1.314 \mathrm{a}$ & $1.322 \mathrm{a}$ & $1.333 \mathrm{a}$ \\
\hline $\mathbf{N}_{3}$ & $1.309 \mathrm{~b}$ & $1.318 \mathrm{~b}$ & $1.328 \mathrm{~b}$ & $\begin{array}{l}1.314 a \\
1300 b\end{array}$ & $\begin{array}{l}1.322 \mathrm{a} \\
1309 \mathrm{~b}\end{array}$ & $1.319 \mathrm{~b}$ \\
\hline $\mathbf{F}_{\text {test }}^{3}$ & $* *$ & $* *$ & $* *$ & $\begin{array}{c}1.300 \mathrm{~b} \\
* *\end{array}$ & $\begin{array}{l}1.309 \mathrm{~b} \\
* *\end{array}$ & $* *$ \\
\hline $\mathbf{H}_{1}^{\text {test }}$ & $1.318 \mathrm{a}$ & $1.328 \mathrm{a}$ & $1.338 \mathrm{a}$ & $1.310 \mathrm{a}$ & $1.319 \mathrm{a}$ & $1.329 \mathrm{a}$ \\
\hline $\mathrm{H}_{2}$ & $1.317 \mathrm{~b}$ & & $1.336 \mathrm{~b}$ & $1.308 \mathrm{~b}$ & $1.317 \mathrm{~b}$ & $1.327 \mathrm{~b}$ \\
\hline $\mathbf{F}_{\text {test }}^{2}$ & $* *$ & $* *$ & $* *$ & $* *$ & $* *$ & $* *$ \\
\hline$I * \mathbf{N}$ & $* *$ & $* *$ & $* *$ & $* *$ & $* *$ & $* *$ \\
\hline $\mathbf{I} * \mathbf{H}$ & $* *$ & $* *$ & $* *$ & $* *$ & $* *$ & $* *$ \\
\hline $\mathbf{N} * \mathbf{H}$ & $* *$ & $* *$ & $* *$ & $* *$ & $* *$ & $* *$ \\
\hline \multirow[t]{2}{*}{$I * \mathbf{N} * \mathbf{H}$} & $* *$ & $* *$ & $* *$ & $* *$ & $* *$ & $* *$ \\
\hline & \multicolumn{5}{|c|}{ Total soil porosity (\%) } & \\
\hline $\mathbf{I}_{1}$ & 50.75 & 50.41 & 50.04 & 51.09 & 50.75 & 49.89 \\
\hline $\mathbf{I}_{2}$ & 50.03 & 49.19 & 49.31 & 50.37 & 5003 & 49.88 \\
\hline $\mathbf{I}_{3}$ & 49.96 & 49.62 & 49.24 & 50.30 & 49.91 & 49.83 \\
\hline $\mathbf{F}_{\text {test }}$ & ns & $\mathrm{ns}$ & ns & ns & ns & ns \\
\hline $\mathbf{N}_{1}$ & $50.07 \mathrm{~b}$ & $49.73 b$ & $49.35 b$ & $50.41 \mathrm{~b}$ & $50.07 \mathrm{~b}$ & $49.69 b$ \\
\hline $\mathbf{N}_{2}$ & $50.07 \mathrm{~b}$ & $49.73 b$ & $49.35 b$ & $50.41 \mathrm{~b}$ & $50.07 \mathrm{~b}$ & $49.69 b$ \\
\hline $\mathbf{N}_{3}^{2}$ & $50.60 \mathrm{a}$ & $50.26 \mathrm{a}$ & $49.88 \mathrm{a}$ & 50.94 & $50.50_{3}$ & $50.21 \mathrm{a}$ \\
\hline $\mathbf{F}_{\text {test }}^{3}$ & $* *$ & $* *$ & $* *$ & $\begin{array}{l}50.94 \mathrm{a} \\
* *\end{array}$ & $* *$ & $* *$ \\
\hline $\mathrm{H}_{1}$ & $50.23 b$ & $49.89 b$ & $49.61 b$ & $50.57 \mathrm{~b}$ & $50.23 \mathrm{~b}$ & $49.85 b$ \\
\hline $\mathbf{H}_{2}$ & $50.27 \mathrm{a}$ & $49.93 a$ & $49.55 \mathrm{a}$ & $50.60 \mathrm{a}$ & $50.27 \mathrm{a}$ & $49.89 a$ \\
\hline $\mathbf{F}_{\text {test }}^{2}$ & $* *$ & $* *$ & $* *$ & $\begin{array}{l}50.00 \mathrm{a} \\
* * *\end{array}$ & $* *$ & $* *$ \\
\hline $\mathbf{I} \mathbf{N}$ & $* *$ & $* *$ & $* *$ & $* *$ & $* *$ & $* *$ \\
\hline $\mathbf{I} * \mathbf{H}$ & $* *$ & $* *$ & $* *$ & $* *$ & $* *$ & $* *$ \\
\hline $\mathbf{N} * \mathbf{H}$ & $* *$ & $* *$ & $* *$ & $* *$ & $* *$ & $* *$ \\
\hline$I * \mathbf{N} \mathbf{H}$ & $* *$ & $* *$ & $* *$ & $* *$ & $* *$ & $* *$ \\
\hline
\end{tabular}

Treatments: $\mathrm{I}_{1}, \mathrm{I}_{2}$ and $\mathrm{I}_{3}$ represent 80,100 and $120 \%$ from standard evaporation pan class A. $\mathrm{N}_{1}: 100 \%$ from recommended nitrogen, $\mathrm{N}_{2}: 80 \%$ from recommended nitrogen + the rest from compost and $\mathrm{N}_{3}: 80 \%$ from recommended nitrogen + the rest from compost, $\mathrm{H}_{1}$ and $\mathrm{H}_{2}: 12$ and $24 \mathrm{~kg} \mathrm{ha}^{-1} \mathrm{~K}$-humate

Env. Biodiv. Soil Security (2019) 


\section{Soil fertility}

The soil fertility plays a great role in supplying cultivated plants with proper and enough nutrients for plant growth. The soil fertility of salt-affected soils is considered an important issue, which needs a suitable management to overcome the salinity and/or sodicity of these soils. The results presented in Table 5 exhibit the effect of different irrigation treatments on soil fertility after harvesting both of sugar beet and cotton crops. Data indicated that available $\mathrm{N}, \mathrm{P}$ and $\mathrm{K}$ in soil were significantly increased by increasing irrigation water since it recorded the highest values up to $80 \%$ evaporation from standard evaporation pan class A. Also data showed that available $\mathrm{N}, \mathrm{P}$ and $\mathrm{K}$ in soil were significantly increased due to the increasing of compost combined with $\mathrm{N}$-fertilizer which the highest values were recorded at treatment
$\mathrm{N}_{3}(60 \% \mathrm{~N}$-mineral $+40 \% \mathrm{~N}$ as compost from recommended nitrogen).With regarding to the effect of applied K-humate on soil fertility, data pointed out that available soil $\mathrm{N}, \mathrm{P}$ and $\mathrm{K}$ were significantly increased with increasing $\mathrm{K}$-humate which the highest values were recorded at level of $24 \mathrm{kgha}^{-1}$. These results supported by Getinet (2016), who reported that application of compost had a positive effect on improving soil fertility

Concerning the interaction among treatments, the same data showed that available N, P and Kin soil after harvesting of sugar beet and cotton yield were significantly increased with different interactions including I*N, I*H and $\mathrm{N} * \mathrm{H}$. However, the highest values were obtained by the interaction among $\mathrm{I}_{1} * \mathrm{~N}_{3} * \mathrm{H}_{2}$. These results are supported by Madeleine et al. (2005) and Wafaa et al. (2017).

TABLE 5. Available nitrogen, phosphour and potassium $\left(\mathrm{mgkg}^{-1}\right)$ in soil as affected by different treatments

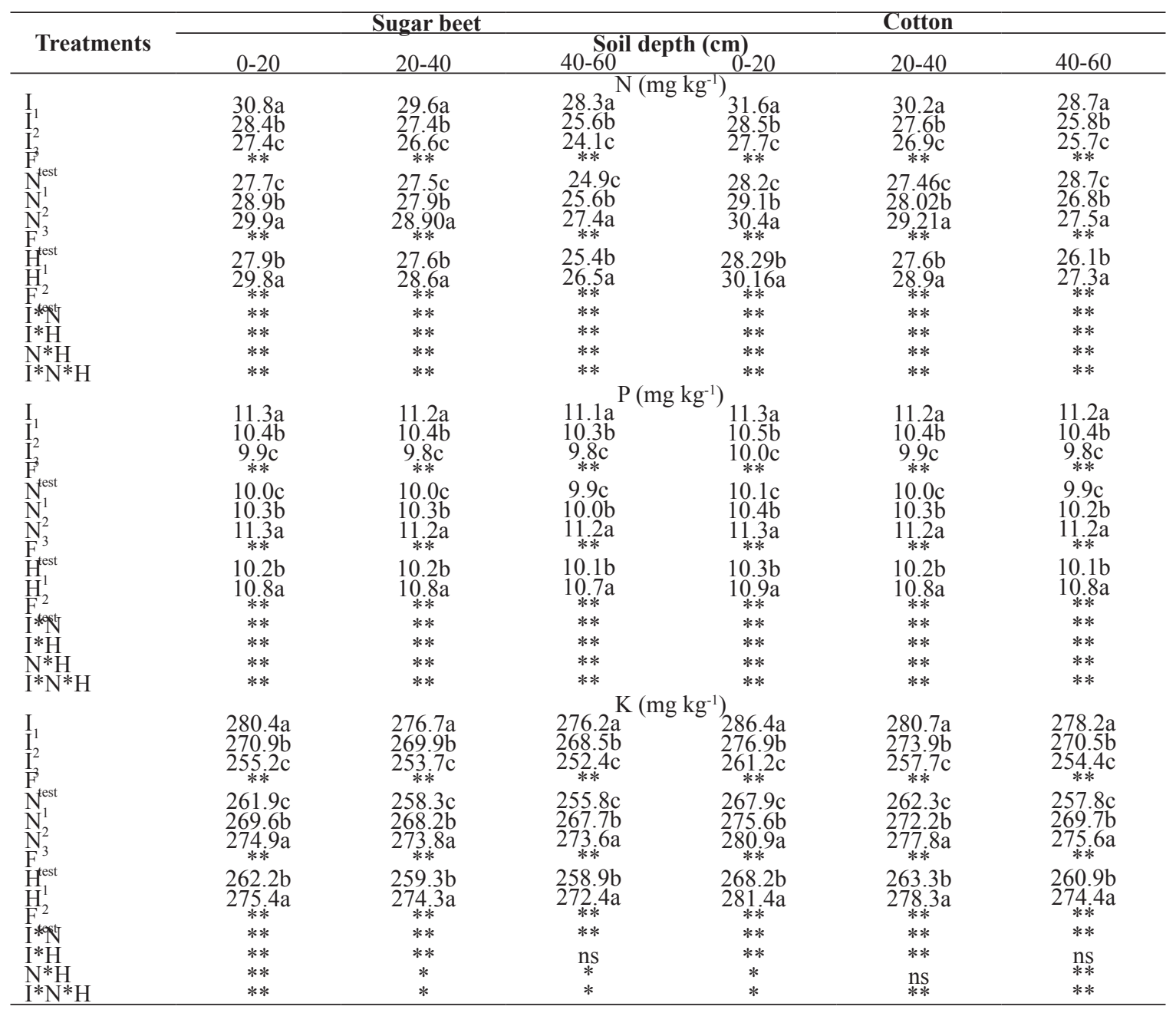

Treatments: $\mathrm{I}_{1}, \mathrm{I}_{2}$ and $\mathrm{I}_{3}$ represent 80,100 and $120 \%$ from standard evaporation pan class A.N $\mathrm{N}_{1}: 100 \%$ from recommended nitrogen, $\mathrm{N}_{2}: 80 \%$ from recommended nitrogen + the rest from compost and $\mathrm{N}_{3}: 80 \%$ from recommended nitrogen + the rest from compost, $\mathrm{H}_{1}$ and $\mathrm{H}_{2}: 12$ and $24 \mathrm{~kg} \mathrm{ha}^{-1} \mathrm{~K}$-humate 


\section{Yield of sugar beet and cotton}

Crop productivity under salt-affected soils may suffer from many problems, which mainly related to the hazard of salinity, sodicity or alkalinity and specific effect of sodium ion. Table 6 and Fig. 3 show the response of sugar beet yields (i.e., shoot, root and sugar) and cotton yield to different irrigation treatments and sources of $\mathrm{N}$-fertilizers as well as applied K-humate and the interactions during the two growing seasons. Data showed that sugar beet yield shoot, root, and sugar as well as cotton yield were significantly increased with increasing irrigation water and recorded the highest values with $\mathrm{I}_{1}$. Data pointed also out that yield of sugar beet and cotton were significantly increased with organic $\mathrm{N}$-fertilizer rate recording the highest values for applied $60 \% \mathrm{~N}$-mineral + $40 \% \mathrm{~N}$ as compost from recommended $\left(\mathrm{N}_{3}\right)$. The yield of sugar beet and cotton were significantly increased with increasing applied K-humate recording the highest value up to $\mathrm{H} 2$. Also the same data showed that shoot, root, sugar and cotton yield were significantly increased due to interaction $\mathrm{I}^{*} \mathrm{~N}, \mathrm{I} * \mathrm{H}$ and $\mathrm{N}^{*} \mathrm{H}$. However the highest values 44.88, 24.05, 9.70 and $2.98 \mathrm{Mg}$ ha-1 for shoot, root, sugar and yield of cotton, respectively were obtained by interaction between $\left(\mathrm{I} 1{ }^{*} \mathrm{~N} 3 * \mathrm{H} 2\right)$ as shown in Fig. 3. These results supported by Getinet (2016) who concluded that nutrients were released from organic compost very slowly to the plants and these nutrients are not directly absorb by the plants. Therefore, plants are unable to access required amount of nutrients in the critical yield-forming period. Hence, an integrated approach, combining application of compost with an application of inorganic fertilizer is a good strategy for increasing crop productivity. This will reduce the cost of inorganic fertilizer and improve soil properties. These results supported by Yonts (2011) expressed that root and sugar yield of sugar beet was the highest for full irrigation and sugar content did not significantly change by reducing irrigation to $25 \%$. Kiziloglu et al. (2006) who indicated that the deficit in the irrigation practices significantly decreased root, leaf, and total sugar yield of sugar beet under semiarid and cold season climatic conditions. There was a linear relationship between evapotranspiration and root yield. Topak et al. (2011) found that root and white sugar yields of sugar beet significantly decreased by the increasing water deficit in the semiarid region.

\section{Conclusion}

It could be concluded that, integrated fertilization including mineral and organic under water stress should be managed in order to sustain the soil and water resources. Due to the water scarcity in particular under arid and semi-arid regions, irrigation water management is considered an important issue and fertilization as well. This study confirmed that, irrigation at $80 \%$ from

TABLE 6. The effect of treatments and their interaction on productivity of cotton and sugar beet crops

\begin{tabular}{|c|c|c|c|c|c|}
\hline \multirow{2}{*}{ Treatments } & \multicolumn{2}{|c|}{ Sugar beet $\left(\mathrm{Mg} \mathrm{ha}^{-1}\right)$} & \multicolumn{3}{|c|}{ Cotton (Mg ha $\left.{ }^{-1}\right)$} \\
\hline & Root & Shoot & White sugar & Seeds & Stalk \\
\hline$T_{1}$ & $42.67 \mathrm{a}$ & $22.61 \mathrm{a}$ & $8.23 a$ & $3.980 \mathrm{a}$ & $4.678 \mathrm{a}$ \\
\hline $\mathrm{I}_{2}$ & $37.54 b$ & $19.46 b$ & $7.27 \mathrm{~b}$ & $3.789 b$ & $4.219 b$ \\
\hline $\mathrm{I}_{3}$ & $34.27 \mathrm{c}$ & $17.28 \mathrm{c}$ & $6.98 \mathrm{c}$ & $3.699 \mathrm{c}$ & $4.017 \mathrm{c}$ \\
\hline $\mathrm{F}_{\text {test }}$ & $* *$ & $* *$ & $* *$ & $* *$ & $* *$ \\
\hline $\mathrm{N}_{1}$ & $35.76 \mathrm{c}$ & $18.34 \mathrm{c}$ & $6.94 \mathrm{c}$ & $3.639 \mathrm{c}$ & $4.97 \mathrm{c}$ \\
\hline $\mathrm{N}_{2}$ & $37.54 b$ & $19.49 b$ & $7.32 \mathrm{~b}$ & $3.803 b$ & $4.292 b$ \\
\hline $\mathrm{N}_{3}$ & $41.18 \mathrm{a}$ & $21.53 \mathrm{a}$ & $8.21 \mathrm{a}$ & $3.996 a$ & $4.421 \mathrm{a}$ \\
\hline $\mathrm{F}_{\text {test }}$ & $* *$ & $* *$ & $* *$ & $* *$ & $* *$ \\
\hline $\mathrm{H}_{1}$ & $37.61 b$ & $19.39 b$ & $7.37 \mathrm{~b}$ & $3.619 b$ & $4.058 b$ \\
\hline $\mathrm{H}_{2}$ & $38.71 \mathrm{a}$ & $20.16 \mathrm{a}$ & 7.61a & 4.006 & $4.552 \mathrm{a}$ \\
\hline $\mathrm{F}_{\text {test }}^{2}$ & $* *$ & $* *$ & $* *$ & $* *$ & $* *$ \\
\hline$I^{*} N$ & $* *$ & $* *$ & $* *$ & $* *$ & $* *$ \\
\hline $\mathrm{I}^{*} \mathrm{H}$ & $* *$ & $* *$ & $* *$ & $* *$ & $* *$ \\
\hline $\mathrm{N}^{*} \mathrm{H}$ & $* *$ & $* *$ & $* *$ & $* *$ & $* *$ \\
\hline $\mathrm{I} * \mathrm{~N} * \mathrm{H}$ & $* *$ & $* *$ & $* *$ & $* *$ & $* *$ \\
\hline
\end{tabular}

Treatments: $\mathrm{I}_{1}, \mathrm{I}_{2}$ and $\mathrm{I}_{3}$ represent 80,100 and $120 \%$ from standard evaporation pan class A. $\mathrm{N}_{1}: 100 \%$ from recommended nitrogen, $\mathrm{N}_{2}: 80 \%$ from recommended nitrogen + the rest from compost and $\mathrm{N}_{3}: 80 \%$ from recommended nitrogen + the rest from compost, $\mathrm{H}_{1}$ and $\mathrm{H}_{2}: 12$ and $24 \mathrm{~kg} \mathrm{ha}^{-1} \mathrm{~K}$-humate

Env. Biodiv. Soil Security (2019) 
standard evaporation pan class A, the optimum nitrogen fertilization strategy for sugar beet and cotton could be combined with $40 \% \mathrm{~N}$ from compost and $60 \%$ mineral-N from recommended as well as $24 \mathrm{~kg} \mathrm{ha}^{-1} \mathrm{~K}$-humate under salt affected soils. It could be also recommended the following crop rotation rice, sugar beet, cotton and berseem or Egyptian clover under studied area conditions. Further studies are needed using different and alternative amendments like municipal solid waste compost, nanomaterials, marine gypsum and elemental sulphur.

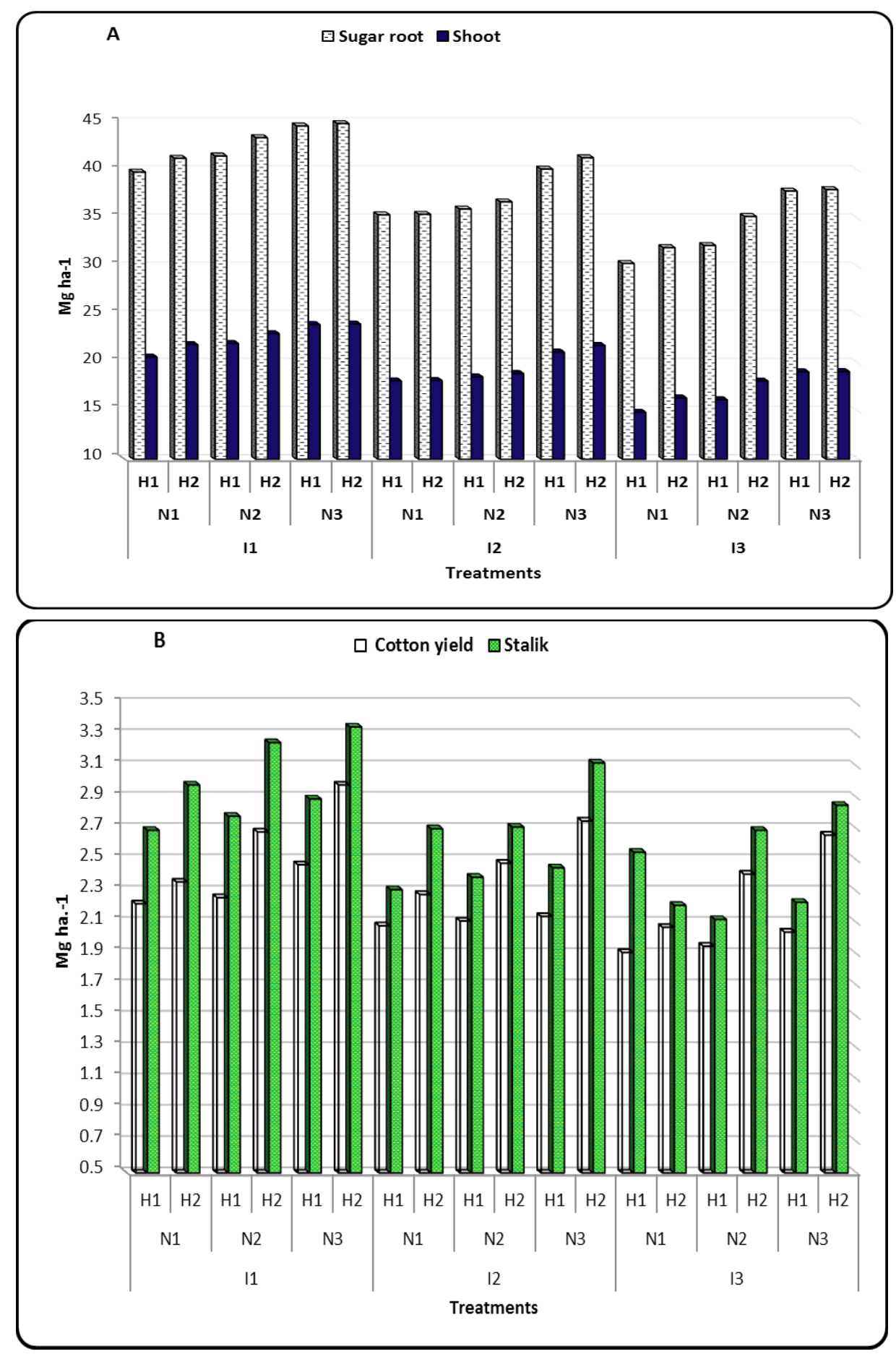

Fig. 3. The yield of sugar beet (A) and cotton as affected by applied different treatments 


\section{$\underline{\text { References }}$}

Abdel- Fattah, M.K. and A.M.A. Merwad (2016) Approach for Reclamation and Improving fertility of saline- sodic soils, Egypt. J. Soil Sci. 56 (4), 573588.

Agegnehu G, van Beek C and M. Bird (2014) Influence of integrated soil fertility management in wheat and tef productivity and soil chemical properties in the highland tropical environment. Journal of Soil Science and Plant Nutrition, 2014, 14

Aiad MA (2019) Productivity of Heavy Clay Soils as Affected by Some Soil Amendments Combined with Irrigation Regime. Env. Biodiv. Soil Security 3: 147162. DOI: $10.21608 / J E N V B S .2019 .14251 .1066$

Amer, M. M and H. R. El-Ramady (2015) Alleviation Soil Salinity and Sodicity Hazard using some biochemical Amendments for Production of canola (Brassica napus L.)in North Delta Region. J. Soil Sci. and Agric. Eng., Mansoura Univ., 6(4): 427 444 .

Amer, M. M. and I. M. Hashem (2018) Impact of Some Soil Amendments on Properties and Productivity of Salt Affected Soils at Kafr El-Sheikh Governorate. Egypt. J. Soil Sci., 58 (2): 177 - 191

Amini S., Ghadiri H., Chen C. and P. Marschner (2016) Salt-affected soils, reclamation, carbon dynamics, and biochar: a review. Journal of Soils and Sediments, 16(3), 939-953.

Amlinger F, Peyr S, Geszti J, Dreher P, Karlheinz W and N. Sortcliff(2007) Beneficial effects of compost application on fertility and productivity of soils. Literature Study, Federal Ministry for Agriculture and Forestry, Envi and Water Management

Arora A (2017) Diagnostic Properties and Constraints of Salt-Affected Soils. In: S. Arora et al. (Ed.), Bioremediation of Salt Affected Soils: An Indian Perspective, DOI 10.1007/978-3-319-48257-6_2, pp: 41 - 52. Springer International Publishing AG

Badr, A.E. (1980) Evaluation of drip irrigation system under Egyptian conditions .Ph.D. Thesis, Agric .Eng. Dept., Fac. of Agric., Cairo Univ., Egypt.

Campbell, D. J. (1994).Determination and use of bulk density in relation to soil compaction. In Soane and Ouwerk (Eds) Soil Compaction in Crop Production Elsever, London and Amsterdam.

Dagar JC, R.K. Yadav, A Singh and N.T. Singh (2019) Historical Perspectives and Dynamics of Nature, Extent, Classification and Management of Salt- affected Soils and Waters. In: J C Dagar et al. (Ed.), Research Developments in Saline Agriculture, pp 3-52, Springer Nature Switzerland AG.

Day SI, J.B. Norton, C.F. Strom, T.J. Kelleners and E.F.Aboukila (2019) Gypsum, langbeinite, sulfur, and compost for reclamation of drastically disturbed calcareous saline-sodic soils. International Journal of Environmental Science and Technology 16:295304 https://doi.org/10.1007/s13762-018-1671-5

Elbasiouny H, F Elbehiry, M Abowaly (2017). Soil Quality Indices; Special Focus on Salt-affected Soil: Review and Case Study in Northern Egypt. Env. Biodiv. Soil Security 1: 85-100. DOI: 10.21608/ JENVBS.2017.1085.1005

El-Henawy, A. S., Atta, M. H. and A. S. Antar (2016) Impact of mole drains and $\mathrm{N}$-fertilizer rates on some soil properties and sugar beet production in clay Soil. Inter. J. Ad. Res., 4 (6), 220-229, http:// www.journalijar.com, DOI:10.21474/IJAR01

El-Ramady H, M Abowaly, F Elbehiry, AE Omara, TA Elsakhawy, S Mohamed, A Belal, H Elbasiouny ZF Abdalla (2019). Stressful Environments and Sustainable Soil Management: A Case Study of Kafr El-Sheikh, Egypt. Env. Biodiv. Soil Security 3: $193-$ 213. DOI: 10.21608/JENVBS.2019.17750.1070

FAO and IIASA (2000) Diagnosis and improvement of saline and alkali sols, USDA Handbook No 60, U.S. Salinity Lab. Staff (1954), Washington

Fatih M.Kiziloglu, Ustun Sahin, IIKKer Anign and O.r Anapali (2006) The Effect of difficit irrigation on water-yield relationship of sugar beet (Beta vulgaris L) under cool season and semi-arid climatic conditions. International sugar Journal voil (108), No, 1286.

Getinet A.dugna( 2016) A review on impact of compost on soil properties, water use and crop productivity. Acad. Res. J. Agri. Sci. Res. (3), 93104. DOI: $10.14662 / A R J A S R 2016.010$

Gomez, K.A.and A.A. Gomez (1984) Statistical Procedures for Agric. Res., 2nd edition. John Wiley and Sons, New York, 680.

Horneck, D.A., Ellsworth, J.W.; Hopkins, B.G.; Sullivan, D.M. and R.G. Stevens (2007) Managing Salt-affected Soils for Crop Production. A Pacific Northwest Extension publication, Oregon State University

Joseph, P.H. (1980) On-Farm Water Budgeting. M.Sc. Thesis, Colorado State University. 
Madeleine I, Peter S, Tim T and V. Tom (2005) Agrodok no. 8: The preparation and use of compost. Agromisa Foundation, Wagenningen.

Mahdy A. M. (2011) Comparative effects of different soil amendments on amelioration of saline-sodic soils. Soil \& Water Res., 6 (4), 205-216.

Mahmood, B.N. and R.N. Ahmad (2005) Determination of water requirements and response of wheat to irrigation at different soil moisture depletion levels. Int. J. Agric. Biol. 7 (5), 812-815.

Masoud, F.I. (1969) Principles of Agricultural irrigation. Dar ELmatbouat Elgadidah, Alexandria (in Arabic).

Mohamed, N.N. (2016) Management of salt-affected soils in the Nile Delta.In:Negm, A. (Ed.), The Nile Delta. Handb. Environ. Chem, vol. 55.Springer, Cham.

Moursi E, RM Khalifa, AM Meleha, and MA Aiad (2019) Effect of Irrigation Scheduling at Different Management Allowable Deficit Using Pan Evaporation on Wheat Yield and Water efficiencies at North Delta. J. Sus. Agric. Sci. 45 (1), 11-25

Page, A. L. R.; Miller H. and D. R. Keeney (1982) Methods of Soil Analysis. Part 2: Chemical and Microbiological Properties. 2nd Edition, Agronomy Monograph, No. 9, ASA, CSSA, and SSSA, Madison.
Sharma DK and A Singh (2017) Current Trends and Emerging Challenges in Sustainable Management of Salt-Affected Soils: A Critical Appraisal. In: S Arora, AK Singh, YP Singh (Eds.), Bioremediation of Salt Affected Soils: An Indian Perspective, pp: pp 1-40. Springer Nature Switzerland AG

Tejada M., Garcia C., Gonzalez J. L. and M. T. Hernandez (2006) Use of organic amendment as a strategy for saline soil remediation: influence on the physical, chemical and biological properties of soil. Soil Biology and Biochemistry, 38 (6), 14131421.

Topak, R., S. Süheri, and B. Acar .( 2011) Effect of different drip irrigation regimes on sugar beet (Beta vulgaris $L$.) yield, quality and water use efficiency in Middle Anatolian, Turkey. Irrigation Science 29,79-89

Wafaa M. T. El-Etr and W. Z. Hassan (2017) Effect of Potassium Humate and Bentonite on some Soil Chemical Properties under Different Rates of Nitrogen Fertilization, J. Soil Sci. and Agric. Eng., Mansoura Univ., 8 (10), 539 - 544.

Yonts, C.D. (2011) Development of season long deficit irrigation strategies for sugar beet. International Sugar Journal 113,728-731. 